\title{
Forming Gears from ZA-27 Zinc Alloy Using Semi-Solid Slurry Squeeze Casting Process
}

\author{
Thawatchai Plookphol, Somjai Janudom, Supakit Vongcharoenpon \\ Department of Mining and Materials Engineering, Faculty of Engineering \\ Prince of Songkla University, Hat Yai, Songkhla 90110, Thailand \\ thawatchai.p@psu.ac.th; somjai.ja@psu.ac.th; supakit.vong@gmail.com
}

\section{Extended Abstract}

Semi-solid metal processing has been developed for years. The semi-solid metal processing can be classified into two types, thixoforming and rheocasting. In recent years, the rheocasting process gains more attention from the industries since it has a lower capital cost and materials cost. Several rheocasting techniques have been invented for preparing semi-solid metal slurries for casting. Gas Induced Semi-Solid (GISS) is a new semi-solid slurry preparation technique recently developed [1]. In the GISS technique, fine inert gas bubbles are injected through a graphite diffuser into the molten alloy, causing a vigorous agitation and a rapid heat extraction from the molten metal, at early stage of solidification the semisolid structure is formed. The GISS technique can be used with many alloys to create semi-solid slurries, such as aluminum alloys, zinc alloys and tin alloys, and it can be used with conventional casting processes, such as die casting, squeeze casting and gravity casting $[2,3]$. The purpose of present study is to evaluate a possibility of using the GISS technique and squeeze casting process for producing gears from a high strength $\mathrm{Zn}-\mathrm{Al}$ alloy. Commercial ZA-27 zinc alloy with nominal chemical compositions of 27-28 wt.\% Al, 2.0-2.5 wt.\% $\mathrm{Cu}$ and the remaining $\mathrm{Zn}$, was used in this study. Effects of rheocasting time and preheating die temperature on the completeness of gear specimens were evaluated. Nitrogen gas was used and the gas bubbles were introduced into molten ZA-27 alloy through a porous graphite diffuser at temperature 510 ${ }^{\circ} \mathrm{C}$ for 10 and $15 \mathrm{~s}$. Two preheating die temperatures, 270 and $300{ }^{\circ} \mathrm{C}$ were used for preheating gear die set before squeeze casting was commenced. Semi-solid alloy slurry was squeezed in the die with a hydraulic compression pressure of 100 $\mathrm{MPa}$ for $30 \mathrm{~s}$. Microstructural analysis and hardness testing were performed on the as-cast gear specimens. It was found that using rheocasting time both 10 and $15 \mathrm{~s}$ and preheating die temperature $270{ }^{\circ} \mathrm{C}$ cannot produce complete gears. Some gear teeth were not completely formed since the cooling rate was too fast and solidification was completed before the alloy slurry could fill up the gear teeth die space. Complete gear specimens were successfully achieved when using rheocasting time $15 \mathrm{~s}$ and preheating die temperature $300{ }^{\circ} \mathrm{C}$. Average hardness of as-cast gear teeth and gear body was $68.3 \pm 2.7$ and $69.6 \pm 1.1 \mathrm{HRB}$, respectively. Microstructures of gear teeth and gear body consisted of globular Al-rich $\alpha$ phase, surrounded by $\beta, \eta$ and $\varepsilon$ phases. Segregation with dendritic structure was formed on the rim of some gear teeth, with thickness of 0.5-1 $\mathrm{mm}$. From the present study it can be concluded that it is possible to form ZA-27 zinc alloy gears using the GISS slurry squeeze casting process by appropriate control process parameters: the rheocasting temperature, the rheocasting time, and the preheating die temperature.

\section{References}

[1] J. Wannasin, R. Martinez and M. Flemings, "Grain refinement of an aluminium alloy by introducing gas bubbles during solidification," Scripta Materialia, vol. 55, pp. 115-118, 2006.

[2] J. Wannasin, S. Janudom, T. Rattanochaikul, R. Canyook, R. Burapa, T. Chucheep and S. Thanabumrungkul, "Research and development of gas induced semi-solid process for industrial applications," Transactions of Nonferrous Metals Society of China, vol. 20, pp. s1010-s1015, 2010.

[3] J. Wannasin, S. Thanabumrungkul and M. Flemings, "Semi-solid die casting using the gas induced semi-solid (GISS) technique,” Die Casting Engineer, pp. 36-40, 2012. 